\title{
Biochemical Responses of Fingerling Cyprinus carpio (Linnaeus, 1758) Exposed to Sub-lethal Concentrations of Dichlorvos
}

\author{
B. Laxmi ${ }^{1}$, K. Madhavi ${ }^{*}$, K. Dhanapal ${ }^{2}$, Adnan Amin ${ }^{1}$, O. Sudhakar ${ }^{3}$ and N. Jesintha ${ }^{4}$ \\ ${ }^{1}$ Department of Aquatic Environment Management, ${ }^{2}$ Department of Fish Processing \\ Technology, ${ }^{3}$ Department of Fisheries Engineering, ${ }^{4}$ Department of Fisheries Resource \\ Management, College of Fishery Science, Muthukur, Nellore District, Andhra Pradesh, India \\ *Corresponding author
}

\section{A B S T R A C T}

\section{Keywords}

Organophosphates,

Dichlovos,

Sub-lethal effects,

Bio-chemical,

Common carp

Article Info

Accepted:

26 September 2020

Available Online:

10 October 2020
The present investigation was taken up under controlled ambient laboratory conditions (conditioning/lethal toxicity/sublethal toxicity studies: $\mathrm{pH}$ : $7.1 \pm 0.2$; salinity: $1 \mathrm{ppt}$; temperature: $32 \pm 2^{\circ} \mathrm{C}$; alkalinity: $220 \pm 18 \mathrm{ppm}$; hardness: $380 \pm 26 \mathrm{ppm}$; dissolved oxygen: $8.0 \pm 0.6 \mathrm{ppm}$ ) to examine the pesticide induced changes in selected biochemical parameters of fingerling common carp exposed to sub-lethal concentrations $\left(1 / 10^{\text {th }} \& 1 / 5^{\text {th }} \mathrm{LC}_{50}\right)$ of dichlorvos. The 96 hour $\mathrm{LC}_{50}$ value was found to be $21.11 \mathrm{ppm}$. The sublethal toxicity impact (either negative or positive) of 'dichlorvos' on biochemical composition of fingerling common carp was in the order of crude fat $>$ ash $>$ moisture $>$ crude protein.

\section{Introduction}

Pesticide contaminations of surface waters have been well documented worldwide and cause a major issue that gives rise to concerns at local, regional, national and global scales due to the adverse effects of pesticide on the environment (Planas et al., 1997). Pesticides contain poisonous substances that distort water quality and impose physiological stress on biotic community of the water body, which is the home of fish. Synthetic pesticides, especially organochlorines and organophosphates have become increasingly important additions to chemical wastes polluting natural aquatic ecosystems and many of these are considered hazardous because of their ability to kill or immobilize organisms even at very low concentrations. Such toxicants reduce the ability of the species to compete in their natural environment by altering the physiological status and inducing morbidity. The harmful effects of pesticides on aquatic organisms are due to indiscriminate use, careless handling, accidental spillage or discharge of untreated 
effluents into natural waterways. There was a shift in the types of insecticides used in the mid $1960^{\circ e} \mathrm{~s}$ from the organochlorine to the less stable organophosphate and carbonate classes (Henry, 1984).

It is realized that these substances are totally alien to aquatic organisms and obviously because of greater intimacy of aquatic organisms with their external environment, the environmental damage caused by the pesticide is perhaps most felt in aquatic ecosystem. This intimacy has made aquatic organisms more vulnerable to even minor changes in their surrounding milieu. It has been recognized, however, that the sensitivity of fish to pesticide varies with species, size and age, it is also known that pesticide toxicity to fish is affected by water hardness and $\mathrm{pH}$. Furthermore, species may differ in the uptake, accumulation, distribution, metabolism and excretion of chemicals. Bioaccumulation rate of pesticides in fish depends on the species, life stages, the amount of fat deposits in different tissues and diet of fish, chemical and physical properties of pesticides etc.

Toxicity tests become imperative to estimate potential hazards as part of risk assessment protocols in ecological sustainability studies. In the science of aquatic toxicology, fish play an important role in toxicity testing and hazard evaluation, as do the white rat and guinea pig in mammalian toxicology (Anon, 1972), especially teleost fish may be a good indicator of pollution as their biochemical responses are almost similar to that of mammals (Banaee et al., 2008).

\section{Materials and Methods}

\section{Test species}

Ready availability throughout the year, ease of maintenance, convenience for testing, good commercial value and economically important as edible fish etc., made us to select Common carp (Cyprinus carpio) as a test species for the present study, besides having been recommended for bioassay experiments by 'Organization for Economic Cooperation and Development (OECD, 1992). The specimens were of 3-months old, with mean length and weight of $5.7 \pm 0.60 \mathrm{~cm}$ and $2.1 \pm$ $0.45 \mathrm{~g}$ respectively.

Common carp fingerlings were collected from nearby fish farm and brought to the laboratory in plastic bags with sufficient air. Upon arrival at the laboratory, fishes were housed in FRP tanks of $1000 \mathrm{~L}$ capacity for 15 days to allow for acclimatization. The fingerlings were fed twice in every 24 hours with dry pellet feed at the rate of $5 \%$ body weight per day and the excreta was siphoned out daily to prevent buildup of ammonia in the medium.

\section{Test substance}

Dichlorvos (as Hyvap which consisted of $76 \%$ EC of dichlorvos)

Dichlorvos is poisonous if swallowed, inhaled, or absorbed through the skin; therefore, it acts as a contact and stomach poison (WHO 1985). Because dichlorvos is one of the more volatile pesticides among organophosphates, it has been used primarily for its fumigant action (Cremlyn 1978). It is effective in controlling nuisance pests (e.g., caterpillars, flies, mosquitoes, and cockroaches) in and around domestic dwellings, stored products, commercial transportation vehicles, and livestock buildings. Dichlorvos also has been added directly to water to control parasites in intensive fish farming (WHO 1989).

\section{Preparation of stock solution}

As $1 \mathrm{gm}$ dichlorvos is approximately equal to $0.76 \mathrm{~mL}$, so as to prepare $1000 \mathrm{ppm}$ stock 
solution, we need to have $0.76 \mathrm{~mL}$ of dichlorvos in $1000 \mathrm{~mL}$ of the solution. As, Hyvap consisted of only $76 \%$ Effective Concentration (EC) of dichlorvos, $1 \mathrm{~mL}$ of hyvap contains dichlorvos of $0.76 \mathrm{~mL}$. So, 1 $\mathrm{mL}$ of Hyvap was added to tap water and finally made it to $1 \mathrm{~L}$, so as to have the stock solution of 1000 ppm dichlorvos.

Test solutions - Test solutions of chosen concentrations were prepared by diluting stock solution.

\section{Lethal toxicity test}

Acute toxicity test was performed following 'static bioassay' method with two replicates, so as to determine $\mathrm{LC}_{50}$ (median lethal concentration) value of dichlorvos to fingerling common carp (active, healthy, disease free) under controlled laboratory conditions (Light: 12 to 14 hours photoperiod; Temperature: $32 \pm 2^{\circ} \mathrm{C} ; \mathrm{pH}: 7.1 \pm 0.2$; Salinity: 1 ppt; Dissolved Oxygen: $8.0 \pm 0.6$ ppm; Alkalinity $220 \pm 18$ ppm and Hardness: $380 \pm 26 \mathrm{ppm}$ and all these mentioned water quality parameters were analyzed following standard methods as per APHA, 2005).

Common carp fingerlings were exposed to definitive concentrations of dichlorvos for a period of 96 hours (as suggested by OECD, 1992) to record the concentrations which resulted in a death of $50 \%$ of the fishes exposed. From this data, later $\mathrm{LC}_{50}$ value was estimated following Finney (1971).

\section{Sub-lethal toxicity studies}

The sub-lethal studies were carried out to understand the changes in selected aspects of biochemical/proximate composition of common carp fingerlings due to exposure to dichlorvos. The sublethal toxicity assay was carried out by selecting two concentrations of LC50 (1/10th and 1/5th of LC50) following semi-static/static renewal bioassay, with three replicates for each selected concentration and control.

Experimental design: Tests were conducted in FRP tanks of $70 \mathrm{~L}$ capacity and filled with $40 \mathrm{~L}$ of tap water. These tanks were stocked at a uniform density of 20 fish/tank. The test solutions were renewed daily by transferring the fish to another tank (semi-static/static renewal bioassay method).The fingerlings were exposed to selected sub-lethal concentrations for 28 days as per the method of Sprague (1971). During the test tenure, animals were fed daily once at the rate of $5 \%$ body weight per day exposed to a fresh solution of the selected concentrations. At every $24 \mathrm{~h}$, the test animals were transferred from one test chamber to another chamber of the same concentration.

Experimental strategy: The following biochemical parameters were estimated at weekly intervals for a period of 28 days from the commencement of experiment i.e., right on the day of test commencement, 7th day, 14th day, 21st day and 28th day (the last day of test tenure) in the two selected sublethal concentrations of the toxicant by sacrificing three (3) fishes from each replicate for each concentration and also from control. All these biochemical tests were performed by following standard methods (AOAC, 1995).

\section{Methodology followed for bio-chemical analysis}

The muscle tissue was homogenized in a hand homogenizer. Moisture content of pre weighed wet sample was determined by drying in hot air oven at a drying temperature of $60^{\circ} \mathrm{C}$ until a constant weight was obtained, then transferred to a desiccator and the difference in weight was calculated and expressed as \% moisture content of the sample. 
The dried samples were finely powered using mortar and pestle and then subjected to standard protocols to estimate the rest biochemical/ proximate components viz. crude protein, crude fat and mineral content (in terms of ash) of the test sample and all the obtained values of these biochemical components were expressed on percentage dry weight basis (\% DWB).

Protein content $(\%=\mathrm{gm} / 100 \mathrm{gm}$ body weight $)$ was determined by multiplying the total nitrogen content (\%) estimated by Kjeldhal method by a factor of 6.25 . Fat content was determined by subjecting the moisture free sample to extraction with petroleum ether and the resultant was considered as crude fat due to the facts that, as petroleum ether results in variable extraction of phospholipids and as also, small amount of fat or other lipids that might have oxidized and formed during drying could not become extractable with petroleum ether. The ash content of a sample of the sample was determined by incineration in a muffle furnace at $550^{\circ} \mathrm{C}$ till the residue became white (Egan et al., 1997).

\section{Results and Discussion}

Lethal toxicity - In the present study, the median lethal concentration (acute toxicity) i.e., $\mathrm{LC}_{50}$ value of dichlorvos to fingerling common carp was found (through probit analysis) to be $21.11 \mathrm{ppm}$. The $\mathrm{LC}_{50}$ observed in the present research is somewhat higher compared to the earlier works of dichlorvos on fingerling common carp. Though the pesticide, fish species, size of the fish seemed to be common to earlier works, as a multitude of factors like genetic properties, health status of test specimen, physico-chemical parameters of water (medium of acclimatization and tests), exposure technique followed, preparation of test solutions of required concentration with due consideration of $\mathrm{EC} \%$ (effective concentration) of active ingredient present in the commercial formulation used etc. influences the $\mathrm{LC}_{50}$ value, one or couple of these factors might have resulted in higher $\mathrm{LC}_{50}$ value. Among the different factors enlisted above, it has been supposed that, water hardness $(380 \pm 26$ ppm) might have played a major role in elevating the $\mathrm{LC}_{50}$ value by reducing the toxicity potential of the test substance (dichlorvos) in the present study, besides good health status of test specimen (fingerling common carp). Under hard water conditions, it has been already proved that, the binding of pesticides with the hardness cations creates molecules which cannot enter into the test specimen, or which enter at a much slower rate, or which precipitate out of solution. Dutta et al., (2002) also noticed a significant reduction (nearly fivefold increase in $\mathrm{LC}_{50}$ value in hard water compared to soft water) in the toxicity of 'deltamethrin' to 'common carp' with increasing hardness of water, and they opined that, the observed lowered toxicity of deltamethrin under hard water conditions might be due to change in the chemistry of biotic receptor sites which might have reduced the permeability of deltamethrin. Gautam and Gupta (2008) reported that, the sensitivity of juvenile Poecilia to 'cypermethrin' was decreased considerably with the increase in hardness of water.

\section{Sub-lethal toxicity studies with respect to changes in bio-chemical composition:}

Protein: The crude protein (\%) content was recorded higher in control group compared to toxicant exposure groups throughout the study period. The percentage change in the protein content in control group by the end of $1^{\text {st }}, 2^{\text {nd }}$, $3^{\text {rd }}$ and $4^{\text {th }}$ quarter seemed to be $-1.79,+0.06$, $1.53 \%$ and $-1.79 \%$. Whereas in toxicant exposed groups continuous decrease in the protein content was observed. In fishes exposed to $1 / 10^{\text {th }} \quad \mathrm{LC}_{50} \quad(2.11 \mathrm{ppm})$ 
concentration, the percentage of decrease in the protein content by the end of first to last quarter includes 5.43, 11.06, 14.77 and $18.54 \%$ respectively. Where as in those exposed to $1 / 5^{\text {th }} \mathrm{LC}_{50}(4.22 \mathrm{ppm})$, it was in the order of $9.5,11.39,15.16$ and $20.88 \%$. By the end of test tenure, compared to the protein content in control group, nearly a 1.21 fold decrease in $1 / 10^{\text {th }} \mathrm{LC}_{50}$, and nearly a 1.26 fold decrease in $1 / 5^{\text {th }} \mathrm{LC}_{50}$ concentrations were observed (Fig. 1). Organophosphates are known to methylate and phosphorylate cellular proteins directly (Wild, 1975) (Table 1).

Table.1

\begin{tabular}{|c|l|l|}
\hline SI. No. & Biochemical parameter & $\begin{array}{c}\text { Percentage of change observed by the end of } \\
\text { exposure to-toxicant free, } \mathbf{1 / 1 0} \mathbf{1 0}^{\text {th }} \mathbf{L C}_{\mathbf{5 0}} \text { and } \\
\mathbf{1 / 5}^{\text {th }} \mathbf{L C}_{\mathbf{5 0}} \text { respectively }\end{array}$ \\
\hline $\mathbf{1}$ & Crude protein & Decreased by $1.79 \%, 18.54 \%$ and $20.88 \%$. \\
\hline $\mathbf{2}$ & Crude fat & Decreased by $0.39 \%, 28.54 \%$ and $41.33 \%$. \\
\hline $\mathbf{3}$ & Ash content & Increased by $2.11 \%, 57.25 \%$ and $113.38 \%$. \\
\hline $\mathbf{4}$ & Moisture content & $\begin{array}{l}\text { Decreased by } 0.34 \%, \text { increased by } 4.03 \% \text { and } \\
8.32 \%\end{array}$ \\
\hline
\end{tabular}

Fig.1 Variations in crude protein $(\%)$ content of fingerling common carp exposed to sublethal concentrations of 'dichlorvos'

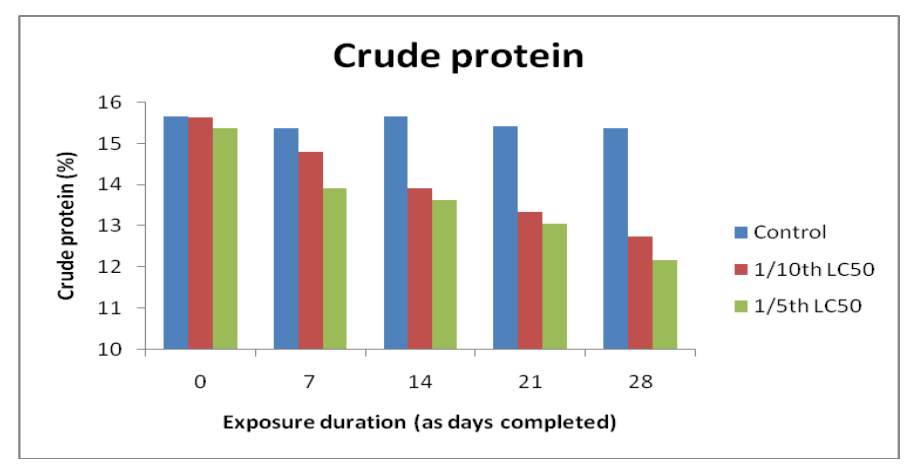

Fig.2 Variations in crude fat $(\%)$ content of fingerling common carp exposed to sublethal concentrations of 'dichlorvos'

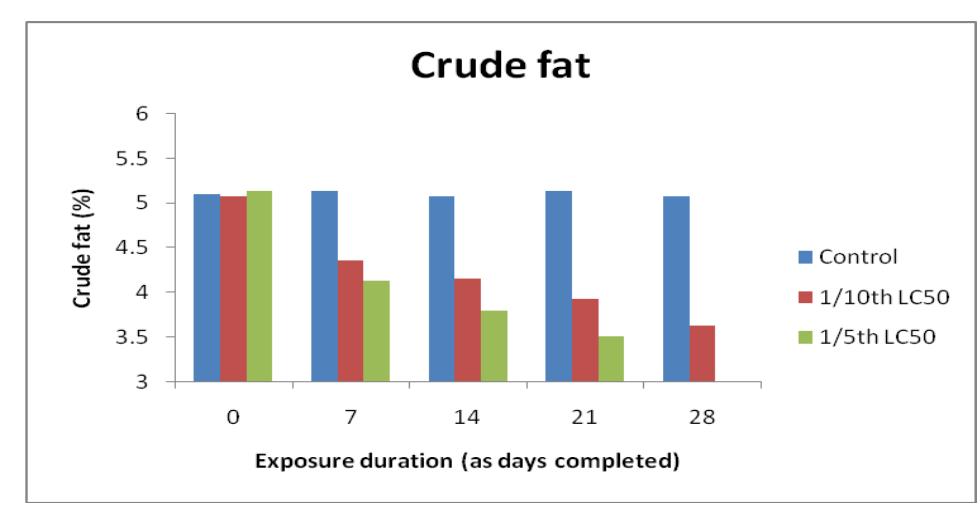


Fig.3 Variations in ash content (\%) of fingerling common carp exposed to sublethal concentrations of 'dichlorvos'

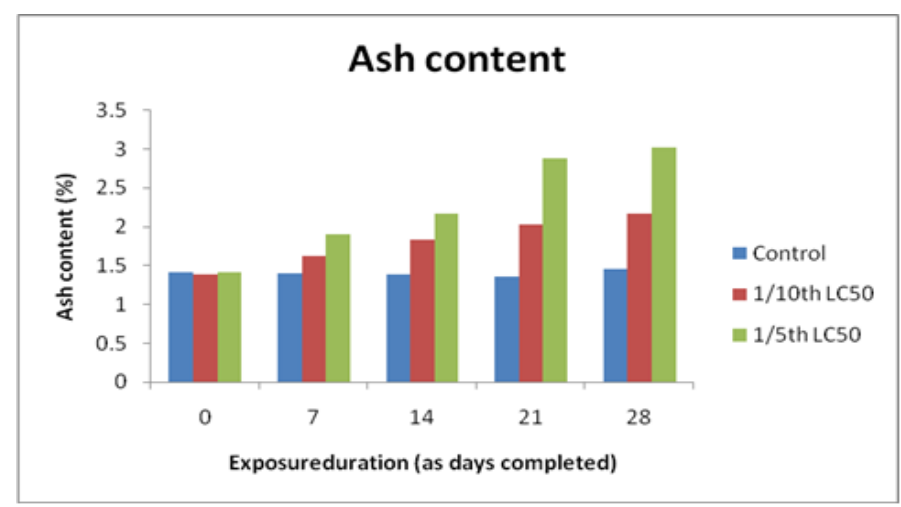

Fig.4 Variations in moisture content (\%) of fingerling common carp exposed to sublethal concentrations of 'dichlorvos'.

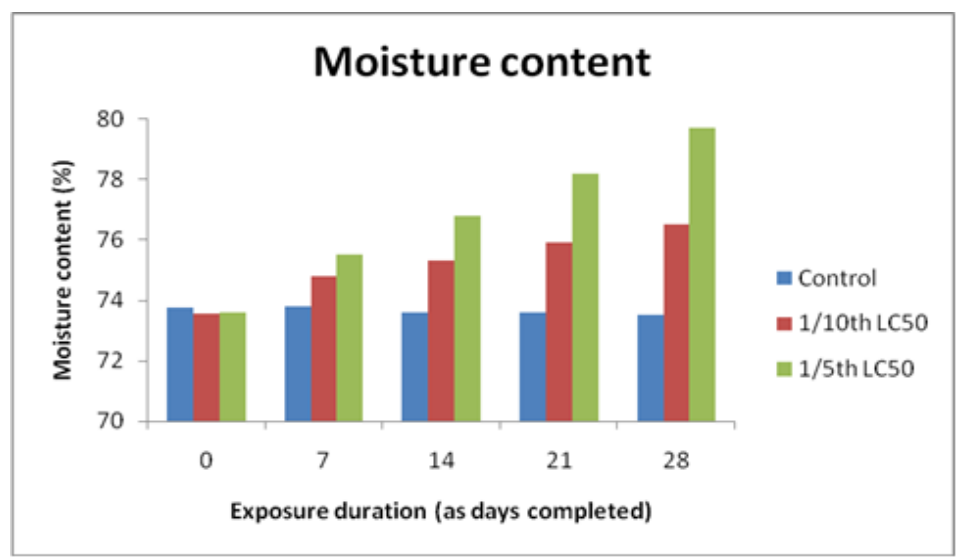

A fall in protein content might be due to the damaged or low protein synthesis under the toxic stress condition. Further as explained by Narra et al., (2011) protein depletion in tissues could be a physiological mechanism with an important role in providing energy to cope with the stress situation. Khan et al., (2016) also reported a decrease in the total protein content of 'grass carp' up on exposure to atrazine.

Fat: Higher crude fat (\%) content was recorded in control groups compared to toxicant exposure groups. In control group, it first increased by $0.59 \%$, then decreased by $0.59 \%$, later increased by $0.78 \%$ and then finally decreased by $0.39 \%$ by the end of $1^{\text {st }}$, $2^{\text {nd }}, 3^{\text {rd }}$ and $4^{\text {th }}$ quarters respectively. The percentage decrease in fat content by the end of $1^{\text {st }}, 2^{\text {nd }}, 3^{\text {rd }}$ and $4^{\text {th }}$ quarters were 14.17 , $18.31,22.64,28.54 \%$ and 19.49, 26.12, $31.58,41.33 \%$ in $1 / 10^{\text {th }} \mathrm{LC}_{50}(2.11 \mathrm{ppm})$ and $1 / 5^{\text {th }} \quad \mathrm{LC}_{50} \quad(4.22 \mathrm{ppm})$ concentrations respectively. Thereby with respect to control, by the end of test tenure, a 73.18 fold decrease in case of $1 / 10^{\text {th }} \mathrm{LC}_{50}$ and a 105.97 fold decrease in case of $1 / 5^{\text {th }} \quad \mathrm{LC}_{50}$ concentrations was observed (Fig. 2). Decline in the lipid levels may be due to the inhibition of cholesterol biosynthesis in the liver or due to reduced absorption of dietary cholesterol as reported by Mishra et al., (2004). Arockia and Milton (2006) also have observed decreasing trend in lipid content of the brain, gill, kidney, liver and muscle tissues upon exposure to lannate in the fish Oreochromis mossambicus. 
Ash: Significantly lower ash (mineral) content $(\%)$ was recorded in control groups throughout the study period, though it showed a weak negative trend in first three quarters with a decrease of $1.41,2.11$ and $4.23 \%$ by the end of $1^{\text {st }}, 2^{\text {nd }}$ and $3^{\text {rd }}$ quarters, but, by the end of last quarter it recorded a positive change i.e., increase by $2.11 \%$. In both toxicant exposure groups, a significant increase was observed right from the beginning till the end of exposure period. In $1 / 10^{\text {th }}$ LC $_{50}$ concentration, the percentage of increase by the end of first to last quarter includes 18.12, 32.61, 47.10 and 57.25\%, whereas in $1 / 5^{\text {th }} \mathrm{LC}_{50}$ concentration, these includes 34.51, 52.82, 103.52, 113.38\%. Thereby with respect to control by the end of test tenure, a 27.13 fold increase in case of $1 / 10^{\text {th }} \mathrm{LC}_{50}$ and a 53.73 fold increase in case of $1 / 5^{\text {th }} \mathrm{LC}_{50}$ concentration was observed (Fig. 3). An increase in ash content further confirmed low dietary protein utilization. Catabolic biochemical reactions might have resulted in increase in ash content. Amin and Indulkar (2017) reported that ash content (\%) of fingerling common carp increased (in control group from 11.82 to 11.85 ; in $1 / 10^{\text {th }}$ $\mathrm{LC}_{50}$ group from 12.06 to 13.11 ; in $1 / 5^{\text {th }} \mathrm{LC}_{50}$ group from 12.38 to 14.33 ) up on exposure to 'imidaclioprid' for a period of 28 days.

Moisture: In control group, by the end of $1^{\text {st }}$ quarter, it increased by $0.07 \%$, then decreased by $0.2 \%$ by the end of $2^{\text {nd }}$ and remained same by the end of $3^{\text {rd }}$ and finally by the end of last quarter a $0.34 \%$ decrease was noticed. In both sublethal concentrations a gradual increase was observed with values $1.71,2.39,3.21$, $4.03 \%\left(1 / 10^{\text {th }} \mathrm{LC}_{50}\right.$ concentration $)$ and 2.61 , $4.38,6.28,8.32 \%\left(1 / 5^{\text {th }}\right.$ of $\left.\mathrm{LC}_{50}\right)$ by the end of $1^{\text {st }}, 2^{\text {nd }}, 3^{\text {rd }}$ and $4^{\text {th }}$ quarters respectively. Thereby a 12.85 fold increase in $1 / 10^{\text {th }} \mathrm{LC}_{50}$ concentration and a 25.47 fold increase in case of $1 / 5^{\text {th }} \quad \mathrm{LC}_{50}$ concentration were observed compared to control by the end of test tenure (Fig. 4). Increase in moisture content could be due to subsequent utilization of muscle protein because of change occurred in energy sources. Soman (1987) also noticed similar trend in $C$. fasciata exposed to 'lebaycid 1000'.

\section{Statistical analysis}

Two-Way ANOVA was consulted to analyze the statistical significance of the present study. From the obtained ' $P$-value, $F$ and $F$ crit.' values (at $\mathrm{p}<0.05)$ for all the parameters under study, it has been found that, there existed a statistically significant difference in the responses (biochemical) of fingerling common carp both to exposure concentration and duration.

In conclusion the biochemical changes (crude protein, crude fat, ash and moisture contents) were estimated at weekly intervals and the observations made on fingerling common carp exposed to Dichlorvos $\left(\mathrm{LC}_{50}\right.$ of 21.11 ppm) for two sub-lethal $\left(1 / 10^{\text {th }} \& 1 / 5^{\text {th }} \mathrm{LC}_{50}\right)$ concentrations are as follows.

The findings of present lethal and sublethal toxicity studies would be helpful in framing guidelines to protect aquatic animals against physiological death (i.e., mortality) and ecological death (i.e., unable to function in an ecological context, due to altered biological activities) respectively.

\section{References}

Amin, A. Indulkar, S.T., and Pai, R., 2017. Sublethal effect of Buprofezin pesticide on carcass composition of Cyprinus Carpio Communis fingerlings. J. Exp. Zool. India., Vol. 20, No. 1, pp. 269-272.

Anon, 1972. EPA bans most DDT uses; readies lead action. Environmental Science and Technology, 6: 675.

AOAC, 1995. Official Methods of Analysis of the Association of Official Analytical Chemists. In: Cunniff $P$ (ed.) Association of Official 
Analytical Chemists, 16th edn. Arlington.

APHA, 2005. Standard Methods for the Examination of Water and Waste Water, American Public Health Association. Washington, DC.

Arockia, J.J. and Mitton, J.M.C., 2006. Effect of carbamate pesticide lannate (methomyl) on the biochemical components of the freshwater cichlid Oreochromis mossambicus (Peters). Ind. J. Environ Ecoplan., 12:263-268.

Banaee, M., Mirvagefei, A.R., Rafei, G.R. and Majazi A. B., 2008. Effect of sub-lethal diazinon concentrations on blood plasma biochemistry. International Journal of Environmental Research, 2: 189-198.

Dutta, S., Kent, Y., Shaht, P. S. and Das R. C. 2002. Effect of some environmental factors on the acute toxicity of deltamethrin to common carp: a laboratory study under aerobic condition. Journal of the Indian Fisheries Association, 31-40.

Egan, H., Kris, R. S., Sawyer, R., 1997. Pearson' s chemical analysis of foods. $E d n$ 9, Longman, London, 634.

Finney, D.J., 1971. Probit analysis. 3rd edn. Cambridge University Press, London. pp: 508-510.

Gautam, P.P. and Gupta, A.K., 2008. Toxicity of cypermethrin to the juveniles of freshwater fish Poecilia reticulata (Peters) in relation to selected environmental variables. Indian Journal of Natural Products and Resources, 7: 314-319.

Henry, C. 1984. Organochlorine residues in a Jamaican river and uptake and elimination of dieldrin by the shrimp Machrobrachium faustinum de Saussure (Msc thesis). University of the west indies, Mona, Jamaica.

Khan,A., Shah, N., Muhammad, Khan, M. S., Ahmad, M. S., Farooq, M., Adnan, M.,
Jawad, S. M., Ullah, H., Yousafzai, A. M., 2016. Quantitative determination of lethal concentration $1 \mathrm{c} 50$ of atrazine on biochemical parameters; total protein and serum albumin of freshwater fish grass carp (Ctenopharyngodonidella). Pol. J. Environ. Stud., Vol. 25, No. 4. 1555-1561.

Mishra, S.K., J. Padhi and L. Sahoo, 2004. Effect of malathion on lipid content of liver and muscles of Anabas testudineus. J. Appl. Zool. Res., 15: 81-82

Narra, Madhusudan Reddy \& Begum, Ghousia \& Rajender, Kodimyala\& Rao, Janapala. (2011). Sublethal effect of chlorpyrifos on protein metabolism of the food fish Clarias batrachus and monitoring of recovery. Toxicological \& Environmental Chemistry. 93. 1-9.

OECD (Organization for Economic Co-operation and Development) (1992). OECD guidelines for testing of chemicals. Fish, Acute Toxicity Test 203:1-9.

Planas, C., Caixach, J., Santos, F.J. and Rivera, J., 1997. Occurrence of pesticides in spanish surface waters. analysis by high resolution gas chromatography coupled to mass spectrometry. Chemosphere, 34: 2393-2406.

Soman, S., 1987. Some observations on the toxicity of the insecticide Lcbaycid 1000 to fresh water fish C. fasciata (Schneider), ph.D. Thesis, Univ of Bombay.

Sprague, J. B., 1971. Measurement of pollutant toxicity to fish--Ill. Sublethal concentrations and "safe" concentrations. Water Research, 245-266.

WHO (1985).Specifcations for Pesticides Used in Public Health, 6th ed., Geneva, pp. 163-168.

WHO, 1989.Dichlolvos (Environmental Health Criteria 79), Geneva, Switzerland.

Wild, D. 1975. Mutagenicity studies on organophosphorus insecticides. Mutat. Res. 32: 135- 150 .

\section{How to cite this article:}

Laxmi, B., K. Madhavi, K. Dhanapal, Adnan Amin, O. Sudhakar and Jesintha, N. 2020. Biochemical Responses of Fingerling Cyprinus carpio (Linnaeus, 1758) Exposed to Sub-lethal Concentrations of Dichlorvos. Int.J.Curr.Microbiol.App.Sci. 9(10): 3250-3257. doi: https://doi.org/10.20546/ijcmas.2020.910.388 